\title{
UPAYA MENINGKATKAN KEMAMPUAN PEMECAHAN MASALAH DENGAN MENERAPKAN MODEL PEMBELAJARAN PENEMUAN BERBANTUAN LEMBAR KERJA PESERTA DIDIK DI SMAN 3 KOTA BENGKULU
}

\author{
Savittriani, Andik Purwanto, Eko Swistoro \\ Prodi Pendidikan Fisika FKIP-UNIB \\ Email: savittriani20@gmail.com
}

\begin{abstract}
ABSTRAK
Penelitian ini bertujuan untuk mendeskripsikan peningkatan aktivitas belajar dan kemampuan pemecahan masalah (KPM) peserta didik. Penelitian ini merupakan penelitian tindakan kelas dengan tiga siklus. Subjek penelitian ini adalah seluruh siswa kelas X IPA 5 yang berjumlah 35 orang. Instrumen peneltian menggunakan lembar observasi dan lembar tes kemampuan pemecahan masalah. Data diolah dengan menggunakan perhitungan statistik dengan mencari nilai rata-rata dan standar deviasi (SD).Hasil penelitian ini menunjukkan bahwa aktivitas belajar peserta didik siklus I rata-rata skor sebesar 34 (kategori cukup), siklus II sebesar 41 (kategori baik), dan siklus III sebesar 45 (kategori baik). Hasil rata- rata nilai kemampuan pemecahan masalah peserta didik siklus I sebesar 72,8 (kategori sedang), meningkat pada siklus II sebesar 79,14 (kategori tinggi), meningkat pada siklus III sebesar 90,11 (kategori tinggi). Berdasarkan hasil penelitian dapat disimpulkan bahwa penerapan model pembelajaran penemuan berbantuan Lembar Kerja Peserta Didik dapat meningkatkan aktivitas belajar dan kemampuan pemecahan masalah peserta didik.
\end{abstract}

Kata Kunci: Model Pembelajaran Penemuan, Lembar Kerja Peserta Didik, Kemampuan Pemecahan Masalah.

\section{ABSTRACT}

This study aims to describe the increase in learning activities and students problem-solving skills (KPM). This study was a classroom action research with three cycles. The subjects of this study were all students of class X IPA 5 which amounted to 35 people. The research instrument uses an observation sheet and a problem solving test sheet. The data was processed by using statistical calculation by finding the mean value and standard deviation (SD). The result of this study showed that the average score of students learning activity in cycle I was 34 (enough category), cycle II was 41 (good category) and cycle III was45 (good category). The average score of students problem solving skills in cycle I was 72,8 (medium category), increased in cycle II was 79,14 (high category), increased in cycle III was 90,11 (high category). Based on the result of the research, it can be concluded that the application of discovery learning model of Student's Work Sheet can improve the learning activity and students problem solving skills.

Keyword: Discovery Learning Model, student worksheet, problem solving skills.

\section{PENDAHULUAN}

Pendidikan merupakan unsur utama dalam mengembangkan manusia Indonesia seutuhnya. Oleh karenanya, pengelolaan pendidikan harus berorientasi kepada bagaimana menciptakan perubahan yang lebih baik ${ }^{[1]}$. Hamalik mendefinisikan pendidikan sebagai suatu proses dalam rangka mempengaruhi siswa agar dapat menyesuaikan diri sebaik mungkin terhadap lingkungannya dengan demikian akan menimbulkan perubahan dalam dirinya yang memungkinkan untuk berfungsi secara akurat dalam kehidupan masyarakat ${ }^{[2]}$. Mutu pendidikan dapat ditingkatkan dengan mewujudkan suasana belajar dan pembelajaran yang berkualitas.

Menurut Achjar Chalil dalam ${ }^{[3]}$ pembelajaran adalah proses interaksi siswa dengan guru

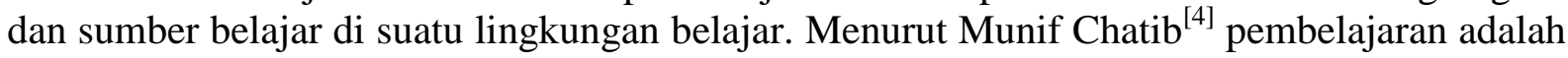
proses transfer ilmu dua arah, yakni antara guru sebagai pemberi informasi dan siswa sebagai penerima informasi. Jadi pembelajaran merupakan proses komunikasi dua arah, yang mana mengajar dilakukan oleh guru, sedangkan belajar dilakukan oleh peserta didik.

Fisika adalah mata pelajaran yang lahir dari ilmu pengetahuan alam yang mempelajari tentang fenomena-fenomena yang sering kita alami di kehidupan sehari-hari. Dalam pembelajaran fisika, bukan hanya membutuhkan pemahaman konsep saja karena fisika 
merupakan pelajaran yang tidak hanya mengandung teori tetapi fisika juga mengandung rumus-rumus yang juga membutuhkan kemampuan pemecahan masalah.

Berdasarkan hasil observasi yang telah dilakukan di kelas X IPA 5 SMAN 3 Kota Bengkulu, pada saat proses pembelajaran berlangsung guru cenderung lebih aktif dibanding peserta didik, guru jarang menggunakan model pembelajaran yang menuntut peserta didik untuk lebih aktif dan menemukan sendiri jawaban dari pembelajaran tersebut, guru tidak menggunakan Lembar Kerja Siswa (LKS) atau Lembar Kerja Pesera Didik (LKPD), dan guru cenderung menjelaskan konsep saja. Dilihat dari kebiasaan ini, ternyata pembelajaran masih belum efektif, masih ada beberapa permasalahan yang dihadapi, diantaranya : 1) peserta didik belum terlibat aktif dalam proses pembelajaran, 2) masih malasnya peserta didik dalam mencari sumber belajar, 3) peserta didik belum terbiasa memecahkan masalah dalam memahami suatu konsep fisika, 4) kurangnya melakukan kegiatan praktikum selama pembelajaran berlangsung, 5) masih banyaknya peserta didik yang mendapatkan nilai dibawah Kriteria Ketuntasan Minimum (KKM) pada mata pelajaran fisika yaitu 76, hal ini dapat terlihat pada nilai ulangan harian semester ganjil mata pelajaran fisika, lebih dari $70 \%$ peserta didik mendapat nilai di bawah Kriteria Ketuntasan Minimum (KKM). Untuk itu diperlukan model pembelajaran yang baik, yang dapat membuat peserta didik dapat terlibat aktif dalam proses pembelajaran.

Berdasarkan hasil diskusi dengan guru mata pelajaran fisika mengenai masalah yang ada di kelas X IPA 5 SMAN 3 Kota Bengkulu diharapkan dapat diatasi dengan menggunakan model discovery learning dan berbantuan dengan Lembar Kerja Peserta Didik (LKPD). Model discovery learning adalah salah satu model yang dapat membuat peserta didik lebih aktif dalam pembelajaran dan dapat menemukan sendiri jawaban untuk memecahkan permasalahan yang dihadapi. Menurut Bruner belajar penemuan (discovery learning) adalah proses belajar dimana guru harus menciptakan situasi belajar yang problematis, menstimulus siswa dengan pertanyaan-pertanyaan, mendorong siswa mencari jawaban sendiri, dan melakukan eksperimen ${ }^{[5]}$. Model discovery learning mengubah kondisi belajar yang pasif menjadi aktif dan kreatif. Mengubah pembelajaran yang teacher oriented dimana guru menjadi pusat informasi menjadi student oriented dimana siswa menjadi subjek aktif belajar [6].

Lembar kerja peserta didik adalah panduan yang digunakan untuk melakukan kegiatan penyelidikan atau pemecahan masalah. Lembar kerja peserta didik dapat berupa panduan untuk latihan pengembangan aspek kognitif maupun panduan untuk pengembangan semua aspek pembelajaran dalam bentuk panduan eksperimen atau demonstrasi ${ }^{[7]}$. Jadi diharapkan peserta didik dapat menemukan sendiri jawaban untuk memecahkan permasalahan yang dihadapinya dengan mengikuti langkah-langkah yang ada di Lembar Kerja Peserta Didik (LKPD).

Kemampuan pemecahan masalah adalah kemampuan seseorang untuk menemukan solusi melalui suatu proses yang melibatkan pemerolehan dan pengorganisasian informasi. Pemecahan masalah melibatkan pencarian cara yang layak untuk mencapai tujuan ${ }^{[8]}$.

Berdasarkan penjelasan diatas maka dibuatlah rumusan masalah yaitu: bagaimana penerapan model discovery learning berbantuan lembar kerja peserta didik pada konsep getaran harmonis dapat meningkatkan kemampuan pemecahan masalah peserta didik di SMAN 3 Kota Bengkulu? dan bagaimana penerapan model discovery learning berbantuan lembar kerja peserta didik pada konsep getaran harmonis dapat meningkatkan aktivitas belajar peserta didik di SMAN 3 Kota Bengkulu?

\section{II.METODE PENELITIAN}

Penelitian ini merupakan penelitian tindakan kelas yang dilaksanakan sebanyak 3 siklus. Subjek dari penelitian ini adalah kelas X IPA 5 SMAN 3 Kota Bengkulu tahun ajaran 
2017/2018, yang berjumlah 35 orang peserta didik, yang terdiri dari 21 orang peserta didik perempuan dan 14 orang peserta didik laki-laki.

Teknik pengumpulan data yang digunakan dalam penelitian ini adalah observasi dan tes akhir siklus. Data yang didapatkan adalah aktivitas peserta didik dan guru, kemampuan pemecahan masalah peserta didik pada setiap siklus. Aktivitas belajar diamati menggunakan lembar observasi pada setiap siklusnya. Penilaian lembar observasi berpedoman pada kriteria penilaian lembar observasi. Kemampuan pemecahan masalah diajarkan melalui lembar kerja peserta didik dan untuk melihat kemampuan pemecahan masalah peserta didik, pada akhir siklus diberikan soal tes evaluasi. Tes evaluasi terdiri dari dua soal essay yang mengandung 9 indikator kemampuan pemecahan masalah.

Aktivitas belajar peserta didik dan aktivitas guru merupakan penilaian observasi dari dua orang pengamat. Dengan kisaran nilai dalam kategori seperti pada tabel 1:

Tabel 1 Interval Kategori penilaian observasi aktivitas belajar peserta didik dan guru

\begin{tabular}{ccc}
\hline No. & Interval & Interprestasi Penilaian \\
1. & $15-25$ & Kurang \\
\hline 2. & $26-35$ & Cukup \\
\hline 3. & $36-45$ & Baik
\end{tabular}

Data tes kemampuan pemecahan masalah dianalisis berdasarkan tahap-tahap dalam memecahkan masalah yang dilakukan oleh peserta didik dan ditentukan melalui rubrik penilaian tes. Kategori kemampuan pemecahan masalah dapat dilihat pada tabel 2:

Tabel 2 Kategori Kemampuan Pemecahan Masalah

\begin{tabular}{ccc}
\hline No. & Nilai & Kategori \\
\hline 1 & $0 \leq$ TKS $\leq 60$ & Rendah \\
\hline 2 & $60 \leq$ TKS $\leq 75$ & Sedang \\
\hline 3 & $75 \leq$ TKS $\leq 100$ & Tinggi \\
\hline & & (Ninik, Hobri, \& Suharto, 2014) ${ }^{[8]}$.
\end{tabular}

Kemampuan pemecahan masalah kemudian dihitung pertahap dengan menggunakan persamaan 1:

$$
\mathrm{KPM}=\frac{\text { Jumlah skor yang diperoleh tahapan } K P M k e-n}{\text { Jumlah skor maksimum tahapan } K P M k e-n} \times 100 \%
$$

$\left(\right.$ Novitri, 2017) ${ }^{[9]}$.

\section{Hasil dan Pembahasan}

\subsection{Hasil}

\subsubsection{Hasil Observasi Aktivitas Belajar Siswa}

Hasil observasi aktivitas belajar peserta didik dari siklus ke siklus dapat dilihat pada gambar 1: 


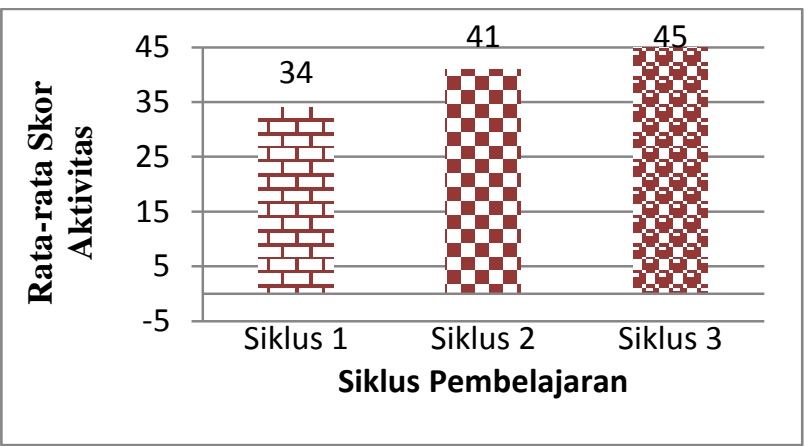

Gambar 1. Grafik Rata-rata hasil Observasi Aktivitas Peserta didik

\subsubsection{Hasil Kemampuan Pemecahan Masalah}

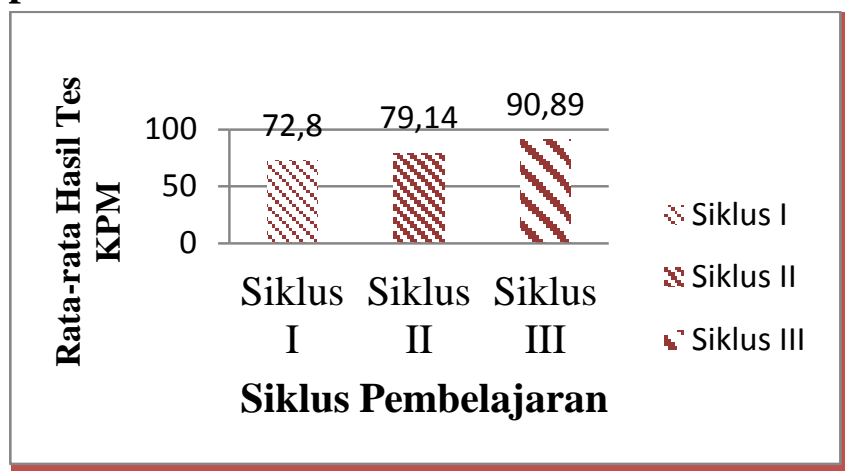

Gambar 1. Grafik Rata-rata Hasil Kemampuan Pemecahan Masalah

Hasil persentase tiap tahapan kemampuan pemecahan masalah peserta didik dapat dilihat dari gambar 3:

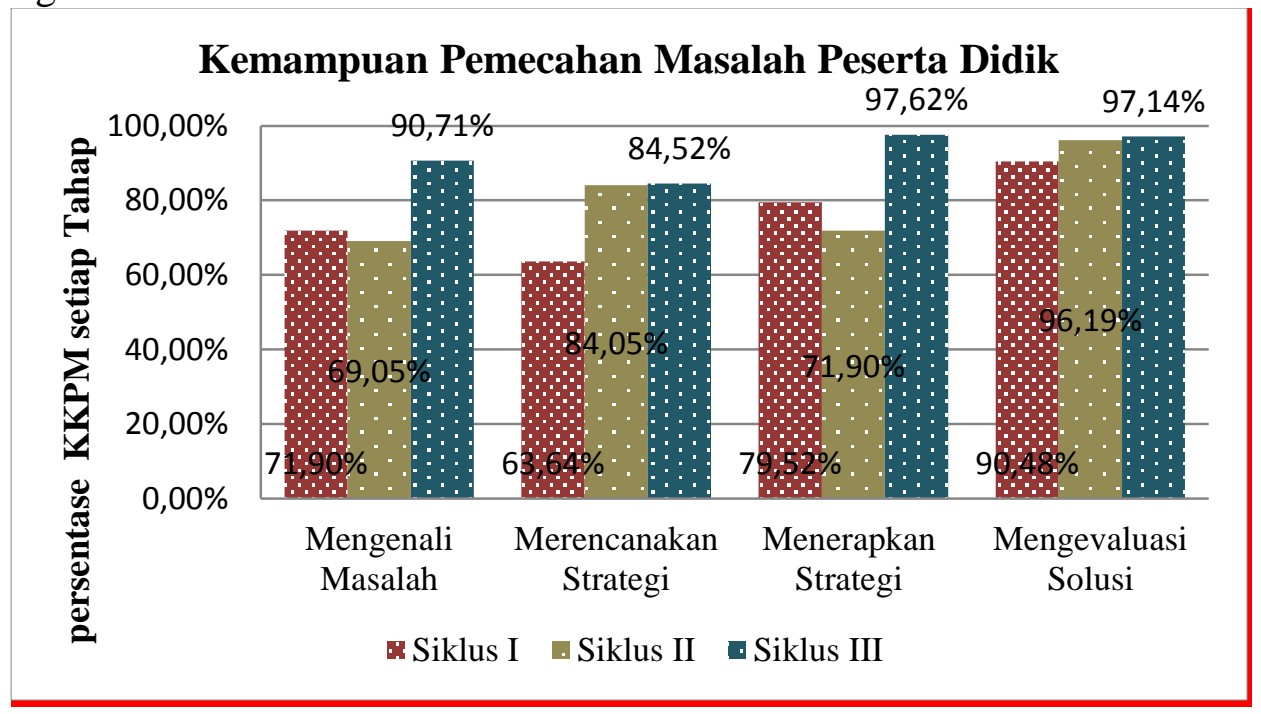

Gambar 3. Rata-rata persentase KPM Peserta Didik setiap tahap

\subsection{Pembahasan}

\subsubsection{Deskripsi Aktivitas Belajar Peserta Didik}

Berdasarkan hasil penelitian pada proses pembelajaran menerapkan model discovery learning berbantuan lembar kerja peserta didik, dari tiga siklus yang telah dilaksanakan terdapat peningkatan aktivitas belajar peserta didik. Peningkatan aktivitas peserta didik terjadi di setiap siklusnya, pada siklus I memperoleh skor rata-rata yaitu 34 (kategori cukup), aktivitas peserta didik kemudian meningkat pada siklus II menjadi 41 (kategori baik), kemudian meningkatan lagi pada siklus III menjadi 45 (kategori baik). Pada pemberian skor 
oleh pengamat untuk beberapa aspek yaitu sama. Hal ini disebabkan karena sebelum memulai pembelajaran guru menjelaskan penilaian kepada pengamat, pada saat pembelajaran berlangsung pengamat juga diberikan rubrik penilaian aktivitas guru dan peserta didik. Peningkatan aktivitas peserta didik berpedoman pada rencana perbaikan yang selalu disusun di setiap siklus. Hasil penelitian ini sejalan dengan penelitian yang pernah dilakukan oleh Rahmad Dwi Kurniawan (2017) dan Yanty Purnama Sari (2016), yang mengemukakan bahwa dengan mengunakan model discovery learning dapat meningkatkan aktivitas belajar siswa.

\subsubsection{Deskripsi Kemampuan Pemecahan Masalah Peserta Didik}

Dapat dilihat siklus I dengan nilai 72,80 kemudian meningkat ke siklus II dengan nilai 79,14 , kemudian meningkat lagi ke siklus III dengan nilai 90,89. Pada siklus I dengan skor 72,80 dengan kategori sedang, pada siklus II dengan skor 79,14 dengan kategori tinggi, dan pada siklus III dengan skor 90,89 dengan kategori tinggi.

Peningkatan kemampuan pemecahan masalah peserta didik dilihat dari penilaian kemampuan peserta didik menyelesaikan soal sesuai dengan indikator kemampuan pemecahan masalah. 1) Mengenali masalah, tahap ini merupakan tahap awal kemampuan pemecahan masalah, pada tahap ini peserta didik di tuntun untuk dapat mengidentifikasi masalah berdasarkan konsep dasar serta peserta didik dituntun untuk menuliskan besaranbesaran yang diketahui dan ditanyakan dari soal. Jika dilihat dari tahap yang lain, tahap ini merupakan tahap yang tidak begitu sulit bagi peserta didik, 2) Merencanakan strategi atau merencanakan jawaban permasalahan, pada siklus I tahap ini merupakan tahap yang lumayan sulit bagi peserta didik karena peserta didik belum terbiasa menyelesaikan soal dengan membuat diagram keterangan gambar permasalahan, dan peserta didik masih kesulitan menentukan persamaan yang digunakan untuk menyelesaikan permasalahan, akan tetapi dengan adanya refleksi atau perbaikan kemampuan peserta didik pada tahap ini meningkat pada siklus II, demikian juga pada siklus III, 3) Menerapkan strategi, yang menjadi kekurangan peserta didik pada tahap ini adalah saat melakukan perhitungan, peserta didik ada yang malas untuk menghitung dan ada juga yang kesulitan dalam melakukan perhitungan. Namun pada siklus II pada tahapan ini nilai yang didapat peserta didik sedikit mengalami penurunan, hal tersebut mugkin dikarenakan perhitungan pada siklus II lebih sulit dibandingkan dengan siklus I, tetapi pada siklus III nilai peserta didik meningkat dibandingkan siklus I dan II, hal tersebut dikarenakan peserta didik mengikuti pembelajaran dengan baik pada siklus ini, 4) Mengoreksi jawaban, tahap ini merupakan tahap yang dianggap mudah oleh peserta didik, karena peserta didik hanya menceklis pilihan Ya/Tidak pada soal tersebut, sehingga pada tahapan ini mengalami peningkatan untuk setiap siklusnya.

Kemampuan pemecahan masalah peserta didik kemudian dianalisis dengan menghitung persentase pertahap, dengan hasil yang didapat yaitu kemampuan pemecahan masalah pada tahap mengenali masalah mengalami penurunan dari siklus I ke siklus II, dan mengalami peningkatan pada sikllus III. Pada tahap merencanakan strategi telah meningkat dari siklus I ke siklus II, dan dari siklus II ke siklus III. Untuk Tahapan menerapkan strategi mengalami penurunan dari siklus I ke siklus II, hal ini kemungkinan disebabkan materi pada siklus II lebih susah dibandingkan dengan materi siklus I namun pada siklus III tahapan ini lebih baik dari pada siklus II dan I. Pada tahap yang terakhir yaitu tahap mengevaluasi solusi, pada tahap ini terjadi peningkatan dari siklus I ke siklus II dan dari siklus II ke siklus III.

\section{Simpulan dan Saran \\ 4.1 Simpulan}

Berdasarkan hasil penelitian dan pembahasan diperoleh kesimpulan sebagai berikut : 1) Penerapan model discovery Learning berbantuan Lembar Kerja Peserta Didik pada konsep getaran harmonis dapat meningkatkan kemampuan pemecahan masalah peserta didik, yaitu kemampuan pemecahan masalah pada siklus I dalam kategori sedang, pada siklus II dalam 
kategori tinggi dan siklus III dalam kategori tinggi, 2) Penerapan model discovery Learning berbantuan Lembar Kerja Peserta Didik pada konsep getaran harmonis dapat meningkatkan aktivitas belajar guru dan peserta didik kelas X IPA 5 SMAN 3 Kota Bengkulu, yaitu aktivitas peserta didik siklus I sebesar 34 dalam kategori cukup, siklus II sebesar 41 dalam kategori baik, dan siklus III sebesar 45 dalam kategori baik.

\subsection{Saran}

Untuk penelitian lebih lanjut sebaiknya memberikan bimbingan dan perhatian yang lebih merata pada setiap kelompok sehingga mengurangi peluang peserta didik bermain-main saat pembelajaran berlangsung. Untuk penelitian selanjutnya disarankan agar mempertimbangkan alokasi waktu pelaksanaan pembelajaran sehingga pembelajaran dapat dilaksanakan dengan efektif tanpa kekurangan waktu.

\section{Daftar Pustaka}

[1] Kurniasih, I., \& Sani, B. (2014). Sukses Mengimplementasikan Kurikulum 2013. Kata Pena.

[2] Cahyo, A. N. (2013). Panduan Aplikasi Teori-teori Belajar Mengajar Teraktual dan Terpopuler. Yogyakarta: DIVA Press.

[3] Putra, S. R. (2013). Desain Belajar Mengajar Kreatif Berbasis Sains. Jogjakarta: DIVA Press.

[5] Wiranataputra, U. S. (2007). Teori Belajar dan Pembelajaran. Jakarta: Universitas Terbuka.

[6] E. Sujarwanto, A. Hidayat, \& Wartono. (2014). Kemampuan Pemecahan Masalah Fisika pada Modeling Instruction pada siswa kelas XI. Jurnal Pendidikan IPA Indonesia, 6578.

[7] Trianto. (2011). Model Pembelajaran Terpadu . Jakarta: PT Buni Aksara.

[8] Ninik, Hobri, \& Suharto. (2014). Analisis Kemampuan Pemecahan Masalah Untuk Setiap Tahap Model Polya Dari Siswa SMK Ibu Pakusari Jurusan Multimedia PadaPokok Bahasan Program Linier. Kadikma, 61-68.

[9] Novitri, M. (2017). Penerapan Model Problem Based Learning dengan Pendekatan Saintifik untuk Meningkatkan Hasil Belajar dan Kemampuan Pemecahan Masalah Siswa Di Kelas VIII.8 SMPN 1 Kota Bengkulu. Bengkulu. 